\title{
Leadership, LMX and teaching process quality in primary schools
}

\section{Лидерство, LMX и квалитет наставног процеса у основним школама}

\author{
Ivan Tasić \\ University of Novi Sad, Technical Faculty "Mihajlo Pupin”, Zrenjanin, Republic of Serbia \\ Miroljub Merdović \\ High Schools "Krug", Novi Sad, Republic of Serbia, \\ srednjaskolakrug@gmail.com \\ Jelena Jankov \\ University of Novi Sad, Technical Faculty "Mihajlo Pupin”, Zrenjanin, Republic of Serbia, \\ jeca25000@gmail.com

\section{Edit Terek} \\ University of Novi Sad, Technical Faculty "Mihajlo Pupin”, Zrenjanin, Republic of Serbia, \\ edit@tfzr.uns.ac.rs

\section{Zoran Jovanović} \\ John Naisbitt University, Belgrade Faculty of Management in Zaječar, Republic of Serbia, \\ zojo30@yahoo.com \\ Milan Nikolić ${ }^{*}$ \\ University of Novi Sad, Technical Faculty "Mihajlo Pupin”, Zrenjanin, Republic of Serbia, \\ mikaczr@sbb.rs
}

\begin{abstract}
The aim of the research in this paper is to examine the direction and intensity of the influence of leadership in schools and the LMX relationship on the teaching process, and the personal and ethical development of pupils. The survey was conducted by means of a questionnaire, and the respondents were teachers in elementary schools in Serbia. A total of 406 valid questionnaires were collected. The average scores of leadership, LMX relationships, the teaching process and pupils' development are high. Transformational leadership is more pronounced than transactional leadership. All the dimensions of leadership, as well as all the aspects of the LMX relationship, have a statistically significant and positive influence on the teaching process, as well as the ethical and personal development of pupils. The strongest influence of leadership and the LMX relation on the dimensions of the teaching process occurs for those dimensions which include activities outside the classroom, while the weakest impact on the teaching process dimensions exists for those dimensions directly related to teaching activities over time. Principals should be more interested in the work of individual teachers and provide them with appropriate feedback. In general, principals should work continuously to improve leadership and LMX relationships.
\end{abstract}

Keywords: Leadership, The LMX Relationship, The Teaching Process, Elementary Schools, Serbia.

JEL classification I21, M12

* Corresponding author 
Сажетак: Циљ истраживања у овом раду је испитивање смера и интензитета утицаја лидерства у школама и односа LMX на наставни процес, као и на лични и етички развој ученика. Истраживање је спроведено путем упитника, а испитаници су били наставници у основним школама у Србији. Прикупљено је 406 упитника. Просечне оцене вођства, LMX односа, наставног процеса и развоја ученика су високе. Трансформационо вођство је израженије од трансакционог. Све димензије лидерства, као и сви аспекти LMX односа, имају статистички значајан и позитиван утицај на наставни процес, као и на етички и лични развој ученика. Најјачи утицај вођства и односа LMX на димензије наставног процеса јавља се за оне димензије које укључују активности изван учионице, док најслабији утицај на димензије наставног процеса постоји за оне димензије директно повезане са наставним активностима током времена. Директори школа би требали бити више заинтересовани за рад појединих наставника и пружити им одговарајуће повратне информације. Генерално, директори школа би требали континуирано да раде на побољшању лидерства и LMX односа.

Кључне речи: Лидерство, LMX однос, наставни процес, основне школе, Србија.

JEL класификација: I21, M12

\section{Introduction}

Leadership in schools, its significance and impact, is the subject of numerous research studies, for example Aubrey et al., 2013; Pashiardis et al., 2011; Hallinger \& Heck, 2010). The reference (Dragojlović et al., 2018) emphasizes the role of school management, which should strive to develop a marketing culture in schools. Such school management and such (marketing) school culture would enable solving current problems in schools, faster response to changes in the environment, offering new services, successful market business, as well as performing activities in accordance with the needs and expectations of internal and external users of services.

When it comes to transformational and transactional leadership in schools, it has been shown that both teachers and students are more accepting of transformational leadership, i.e. leadership that prefers a strategic approach, intellectual stimulation, support for followers, and common multiple goals. For example, according to Bogler et al. (2013), transformational leadership is more appropriate for pupils than passive leadership, and the style of teacher leadership reflects on students' satisfaction. In Jordan, transformational leadership significantly and positively influences teachers' organizational commitment (Khasawneh et al., 2012). Hallinger and Heck (2010) found that transformational leadership directly affects academic capacities, and indirectly affects students' achievements.

In addition to business organizations, LMX theory is also important in educational organizations. However, the impression is that, with regard to educational institutions, this topic has not been given due attention in previous studies. Some references explore LMX theory in the field of education. Thus, for example, according to (Ross et al., 2017), in educating managers, it is important to study LMX theory because it has an impact on fair relations within organizations. In the reference (Brimecombe et al., 2014), the importance of LMX theory and the influence of LMX 
on the performance of employees in the education of athletes and managers in sports are pointed out. A survey conducted in secondary schools in Turkey showed that a quality LMX relationship may compensate for teachers' possible dissatisfaction with their work and careers (Erdogan et al., 2004). According to the research (Somech, 2003), where the respondents were teachers, LMX theory has been shown to significantly explain the relationship between the participatory behaviour of the leaders and the personal variables of the leaders (gender, age, years of service, education).

The aim of the research in this paper is to examine the direction and intensity of the influence of leadership in schools (transformational and transactional) and the LMX relation on the teaching process, and the personal and ethical development of pupils. The survey is conducted by means of a questionnaire, and the respondents are teachers in elementary schools in Serbia. Such research certainly has its significance stemming from the fact that teachers in elementary schools in Serbia are often not satisfied with their work, and their income in particular. Under conditions where significant improvements in the salaries in the education sector are unlikely to occur in the short term, additional ways of increasing teacher satisfaction should be found, as well as their motivation to improve the teaching process. Attention must be focused on school leadership, its improvement, and the improvement of LMX relationships.

\section{Theory and hypotheses}

\subsection{Leadership}

The difference between transformational and transactional leadership was first noticed and defined by Burns (1978). Burns notes that transformational leadership is based on the motivation of the follower to achieve organizational goals, and that transactional leadership is based on the motivation of followers by means of rewards and punishments.

Transformational leaders focus their attention on the relationships and relations with their followers (Cannella \& Monroe, 1997). Transformational leaders strive to raise the level of consciousness of their followers by promoting moral values and "more" emotions and goals, which include freedom, justice, equality, peace and others.

Transactional leaders act completely differently. They motivate followers by pointing them towards their own interests. If the followers work at the required level, the transactional leader tends to provide them with appropriate rewards (Burns, 1978). Otherwise, if they do not achieve the required performance, then the transactional leader applies penalties for such followers. Bryman (1992) confirms that the behaviour of a transactional leader involves two behaviours: behaviour through rewards and behaviour through punishment. 
Most authors (for example Howell et al., 2005; MacKenzie et al., 2001; Ling et al., 2008), agree that transformational leadership has a greater impact on organizational performance, with this impact being positive. The dominance of transformational leadership over transactional leadership is indirectly indicated by recent research by other authors. For example, in their work, Erić Nielsen, Stojanović-Aleksić and Zlatanović (2019, p. 95) conclude that "competitive potential of an organization can be fully exploited only under appropriate circumstances, in a friendly and nurturing internal environment." Similarly, Sokolov et al. (2019, p. 62) note that "the effectiveness of leadership comes from the ability of the leader to inspire, communicate and coordinate within the group, solve problems and learn. Leadership is motivation."

There is a continuing need to improve existing and develop new leadership styles that will meet the increasingly complex requirements of contemporary business. Thus, according to Stojanović and Marić (2018), contemporary organizations, especially knowledge-based organizations, require a greater number of adequate leadership styles, for example: (a) involving all employees in leadership processes, in order to ensure responsible self-leadership and effectively shared -leadership; (b) Complexity Leadership Theory; (c) Complex Adaptive Systems; (d) Adaptive leadership, and other.

\subsection{LMX theory of leadership}

It has long been known that human resources are the bearers of working potential, and as such, can certainly be used to achieve the organizational goals (Đorđević et al., 2019). Strukan, Terek and Nikolić (2019) believe that the work of leaders, in essence, involves working with people, and that the key of good leadership is in relation to people. As a result, leaders are strongly focused on developing quality interpersonal relationships in the leader-member relationship (LMX leadership).

LMX theory (Leader Member Exchange theory) measures and studies the quality of relationships, support, and trust between the leaders and members of an organization (Seabright et al., 1992). According to (Dansereau et al., 1975), LMX theory deals with relationships and relations between leaders (superiors) and followers (subordinates).

In the case of a high-quality LMX relationship, there is mutual support between the leader and followers, with the exchange of formal and informal rewards (Dienesch \& Liden, 1986). Similarly, Graen and Uhl-Bien (1995) emphasize mutual trust, respect, mutual influence, loyalty, connection and a sense of commitment towards their superiors in the case of a high quality LMX relationship. According to a number of references, for example, (Ferris et al., 1991; Pellegrini \& Scandura, 2006; Erdogan \& Enders, 2007), a high quality LMX relationship has a positive impact on various factors of organizational performance. 
Based on previous exposure, one basic and eight specific hypotheses can be set in this research. The basic hypothesis:

H0: Leadership and the LMX relationship have a statistically significant impact on the quality of the teaching process and the personal and ethical development of pupils in elementary schools in Serbia.

Specific hypotheses:

H1a: The leadership dimensions have statistically significant correlations with the dimensions of the quality of the teaching process.

H1b: The leadership dimensions have statistically significant correlations with the dimensions of the personal and ethical development of pupils.

H1c: The leadership dimensions have a statistically significant predictive effect on the quality of the teaching process.

H1d: The leadership dimensions have a statistically significant predictive effect on the dimensions of the personal and ethical development of pupils.

H2a: The relationship between the principal and teachers (LMX relationship) has statistically significant correlations with the dimensions of the quality of the teaching process.

H2b: LMX relationship has statistically significant correlations with the dimensions of the personal and ethical development of pupils.

H2c: LMX relationship has a statistically significant predictive effect on the quality of the teaching process.

H2d: LMX relationship has a statistically significant predictive effect on the dimensions of the personal and ethical development of pupils.

\section{Research methodology}

\subsection{Research instruments}

Transformational leadership. The Transformational Leadership Behavior Inventory (TLI) questionnaire was used to measure transformational leadership (Podsakoff et al., 1990). The questionnaire comprises 14 items arranged in four dimensions. The respondents evaluated each item with scores ranging from 1 to 7 .

Transactional leadership. For the measurement of transactional leadership, a questionnaire developed in the following references was used (Podsakoff et al. 1984; MacKenzie et al., 2001). The questionnaire consists of seven items distributed in two dimensions. All of the items were rated on a seven point Likert scale. 
Leader-member exchange (LMX). The LMX-7 questionnaire (Graen \& UhlBien, 1995) was used to measure the LMX relationship. This is a questionnaire comprising seven items, which make up one dimension (a one-dimensional LMX questionnaire). All of the items were rated by a five-point Likert scale.

The teaching process, the personal and ethical development of pupils. In order to measure the quality of the teaching process and the personal and ethical development of the pupils, the Manual for the Evaluation and Self-Evaluation of School Work questionnaire, developed by the Ministry of Education and Sports of the Republic of Serbia in cooperation with the British Council Serbia and Montenegro (Bojanić et al., 2005) was used. The questionnaire for measuring the quality of the teaching process consists of 80 items distributed in ten dimensions. The questionnaire for measuring the personal and ethical development of pupils includes 30 items distributed in two dimensions. All of the items were rated on a four-point Likert scale.

\subsection{Data on the procedure and survey sample}

The research was conducted in elementary schools in Serbia. In doing so, interviews were conducted with the respondents. The respondents were teachers. A total of 406 valid questionnaires were collected from 62 elementary schools.

\section{Research results}

\subsection{Results of the descriptive statistics}

The results of the descriptive statistics are given in Table 1.

Table 1: The results of descriptive statistics

\begin{tabular}{|c|c|c|c|c|c|c|c|}
\hline Dimensions and items & Abbr. & $\mathrm{N}$ & Min & Max & Mean & $\begin{array}{l}\text { Std. } \\
\text { Dev. }\end{array}$ & $\alpha$ \\
\hline $\begin{array}{l}\text { The basic transformational behavior of } \\
\text { the leader }\end{array}$ & L1 & 406 & 1.00 & 7.00 & 5.577 & 1.428 & .954 \\
\hline Expecting high performance & L2 & 406 & 1.00 & 7.00 & 5.674 & 1.238 & .897 \\
\hline $\begin{array}{l}\text { Incentive Behavior of a Leader } \\
\text { (Understanding, Feeling) }\end{array}$ & L3 & 406 & 1.00 & 7.00 & 5.362 & 1.598 & .972 \\
\hline Intellectual stimulation & L4 & 406 & 1.00 & 7.00 & 5.380 & 1.488 & .965 \\
\hline Part of the incentive behavior (rewards) & L5 & 406 & 1.00 & 7.00 & 5.165 & 1.660 & .946 \\
\hline Part of punishing behavior (punishment) & L6 & 406 & 1.00 & 7.00 & 5.239 & 1.436 & .903 \\
\hline LMX & LMX & 406 & 1 & 5 & 3.87 & .926 & .943 \\
\hline $\begin{array}{l}\text { To what extent have you been informed } \\
\text { that your principal is happy or dissatisfied } \\
\text { with your work? }\end{array}$ & LMX1 & 406 & 1 & 5 & 3.70 & 1.080 & \\
\hline $\begin{array}{l}\text { To what extent does your principal } \\
\text { understand your work problems and } \\
\text { needs? }\end{array}$ & LMX2 & 406 & 1 & 5 & 3.84 & 1.102 & \\
\hline To what extent do you feel your principal & LMX3 & 406 & 1 & 5 & 3.88 & 1.074 & \\
\hline
\end{tabular}


recognizes your potentials?

To what extent is your principal ready to $\begin{array}{lllllll}\text { use the acquired power to help you solve } & \text { LMX4 } & 406 & 1 & 5 & \mathbf{3 . 9 0} & 1.070\end{array}$ workplace problems?

To what extent is your principal ready to $\begin{array}{llllll}\text { "back you up" even at his own risk, if you LMX5 } & 406 & 1 & 5 & \mathbf{3 . 7 3} & 1.189\end{array}$ really need it?

To what extent do you have confidence in $\begin{array}{llllllll}\text { the decisions of the principal to defend } & \text { LMX6 } & 406 & 1 & 5 & \mathbf{4 . 0 0} & .989\end{array}$ them?

How would you characterize the effectiveness of your working relationships with the principal?

\begin{tabular}{lccccccc}
\hline Lesson planning & TP1 & 406 & 1.00 & 4.00 & $\mathbf{3 . 5 4}$ & .419 & .820 \\
Preparing classes & TP2 & 406 & 1.62 & 4.00 & $\mathbf{3 . 6 0}$ & .400 & .888 \\
Communication and cooperation & TP3 & 406 & 2.13 & 4.00 & $\mathbf{3 . 8 6}$ & .279 & .875 \\
Rationality and organization & TP4 & 406 & 2.25 & 4.00 & $\mathbf{3 . 6 9}$ & .351 & .856 \\
Encouraging pupils & TP5 & 406 & 2.00 & 4.00 & $\mathbf{3 . 7 7}$ & .322 & .880 \\
Correlation and application of knowledge & TP6 & 406 & 2.20 & 4.00 & $\mathbf{3 . 6 5}$ & .406 & .739 \\
Responsibility of pupils & TP7 & 406 & 2.00 & 4.00 & $\mathbf{3 . 6 3}$ & .415 & .800 \\
The way of learning & TP8 & 406 & 2.29 & 4.00 & $\mathbf{3 . 7 4}$ & .351 & .857 \\
Monitoring and evaluation & TP9 & 406 & 2.36 & 4.00 & $\mathbf{3 . 7 7}$ & .316 & .885 \\
Reporting & TP10 & 406 & 1.60 & 4.00 & $\mathbf{3 . 6 4}$ & .468 & .862 \\
\hline Personal development of pupils & SPD & 406 & 2.13 & 4.00 & $\mathbf{3 . 7 3 1}$ & .322 & .882 \\
Ethical development of pupils & SED & 406 & 2.33 & 4.00 & $\mathbf{3 . 6 5 2}$ & .372 & .888 \\
\hline
\end{tabular}

Source: Authors' own research

\subsection{Results of the leadership influence}

The correlation analysis between the dimensions of leadership and the quality of the teaching process is given in Table $2(* \mathrm{p}<0.05 ; * * \mathrm{p}<0.01)$, and the correlation analysis between the dimensions of leadership and the personal and ethical development of the pupils is given in Table $3(* \mathrm{p}<0.05 ; * * \mathrm{p}<0.01)$.

Table 2. The correlations between leadership and the teaching process

\begin{tabular}{|c|c|c|c|c|c|c|c|c|c|c|}
\hline & TP1 & TP2 & TP3 & TP4 & TP5 & TP6 & TP7 & TP8 & ТP9 & TP10 \\
\hline L1 & $458^{* *}$ & $.352^{* *}$ & $214^{* *}$ & $287^{* *}$ & $268^{* *}$ & $.226^{* *}$ & $279^{* *}$ & $209^{* *}$ & $318^{* *}$ & $356^{* *}$ \\
\hline L2 & $.403^{* *}$ & $.332^{* *}$ & $.223^{* *}$ & $.261^{* *}$ & $.249^{* *}$ & $.194^{* *}$ & $.252^{* *}$ & $.224^{* *}$ & $.307^{* *}$ & $.185^{* *}$ \\
\hline L3 & $.342^{* *}$ & $.223^{* *}$ & $.134^{* *}$ & $.166^{* *}$ & $.185^{* *}$ & $.127^{*}$ & $.166^{* *}$ & $.129^{* *}$ & $.185^{* *}$ & $.285^{* *}$ \\
\hline L4 & $.444^{* *}$ & $.405^{* *}$ & $.217^{* *}$ & $.287^{* *}$ & $.299^{* *}$ & $.257^{* *}$ & $251^{* *}$ & $.251^{* *}$ & $.313^{* *}$ & $.325^{* *}$ \\
\hline L5 & $.444^{* *}$ & $.301^{* *}$ & $.177^{* *}$ & $.260^{* *}$ & $.255^{* *}$ & $.173^{* *}$ & $231^{* *}$ & $.156^{* *}$ & $.233^{* *}$ & $.333^{* *}$ \\
\hline L6 & $.356^{* *}$ & $.246^{* *}$ & $.112^{*}$ & $164^{* *}$ & $.142^{* *}$ & $.137^{* *}$ & $162^{* *}$ & $.103^{*}$ & $.179^{* *}$ & $.120^{*}$ \\
\hline
\end{tabular}

Source: Authors'own research 
Ivan Tasić, Miroljub Merdović, Jelena Jankov, Edit Terek,

Table 3. The correlations between leadership and the personal and ethical development of the pupils

\begin{tabular}{lll}
\hline & SPD & SED \\
\hline L1 & $.364^{* *}$ & $.485^{* *}$ \\
L2 & $.279^{* *}$ & $.327^{* *}$ \\
L3 & $.273^{* *}$ & $.390^{* *}$ \\
L4 & $.371^{* *}$ & $.454^{* *}$ \\
L5 & $.335^{* *}$ & $.430^{* *}$ \\
L6 & $.232^{* *}$ & $.272^{* *}$ \\
\hline
\end{tabular}

Source: Authors' own research

Linear regression analysis was applied in order to examine the predictive effect of leadership on the quality of the teaching process and the personal and ethical development of students. The results are shown in Tables 4 and 5.

Table 4. The results of the regression analysis: the predictive effect of leadership on the teaching process

\begin{tabular}{c|cccccc|ccc}
\hline & \multicolumn{7}{|c|}{ Independent } \\
Dep. & L1 & L2 & L3 & L4 & L5 & L6 & $\mathrm{R}^{2}$ & $\mathrm{~F}$ & Sig. \\
& & & \multicolumn{2}{c}{$\beta$} & & & & & \\
TP1 & $.261^{* *}$ & $.196^{* *}$ & $.248^{* *}$ & .026 & $.300^{* *}$ & .063 & .275 & 25.196 & .000 \\
TP2 & .148 & .104 & $.363^{* *}$ & $.420^{* *}$ & .125 & -.042 & .203 & 16.922 & .000 \\
TP3 & .139 & $.170^{*}$ & $.213^{*}$ & .101 & .125 & -.081 & .073 & 5.261 & .000 \\
TP4 & $.202^{*}$ & $.155^{*}$ & $.362^{* *}$ & .145 & $.255^{* *}$ & -.091 & .132 & 10.088 & .000 \\
TP5 & .094 & .127 & $.283^{* *}$ & $.253^{* *}$ & $.209^{*}$ & .113 & .117 & .8843 & .000 \\
TP6 & .132 & .032 & $.253^{* *}$ & $.325^{* *}$ & .038 & -.044 & .087 & 6.331 & .000 \\
TP7 & $.257^{* *}$ & $.166^{*}$ & $.258^{* *}$ & .014 & .177 & -.052 & .107 & 7.959 & .000 \\
TP8 & .081 & .125 & $.229^{* *}$ & $.315^{* *}$ & .027 & -.109 & .087 & .6369 & .000 \\
TP9 & $.267^{* *}$ & $.186^{*}$ & $.290^{* *}$ & .169 & .079 & -.076 & .146 & 11.357 & .000 \\
TP10 & $.258^{* *}$ & -.040 & .140 & .146 & $.208^{*}$ & -.108 & .149 & 11.603 & .000 \\
\hline
\end{tabular}

Source: Authors'own research

Table 5. The results of the regression analysis: the predictive effect of leadership on the personal and ethical development of the pupils

\begin{tabular}{|c|c|c|c|c|c|c|c|c|c|}
\hline \multirow[b]{2}{*}{ Dep. } & \multicolumn{6}{|c|}{ Independent } & \multirow[b]{2}{*}{$\mathrm{R}^{2}$} & \multirow[b]{2}{*}{$\mathrm{F}$} & \multirow[b]{2}{*}{ Sig. } \\
\hline & L1 & L2 & L3 & L4 & L5 & L6 & & & \\
\hline SPD & $.199^{*}$ & .041 & $.201^{*}$ & $.208^{*}$ & .168 & -.007 & .161 & 12.742 & .000 \\
\hline SED & $.334^{* *}$ & .013 & .099 & .132 & .144 & .044 & .250 & 22.200 & .000 \\
\hline
\end{tabular}

Source: Authors' own research

\subsection{Results of the impact of the LMX relationships}

The correlation analysis between the LMX relationship and the dimension of the teaching process is given in Table $6\left({ }^{*} \mathrm{p}<0.05 ;{ }^{* *} \mathrm{p}<0.01\right)$, and the correlation analysis between the LMX relationship and the dimensions of the pupils' personal and ethical development is given in Table $7\left({ }^{*} \mathrm{p}<0.05 ;{ }^{*} \mathrm{p}<0.01\right)$. 
Table 6. The correlations between the LMX relationship and the quality of the teaching process

\begin{tabular}{|c|c|c|c|c|c|c|c|c|c|c|}
\hline & TP1 & TP2 & TP3 & TP4 & TP5 & TP6 & TP7 & TP8 & TP9 & TP10 \\
\hline LMX1 & $.365^{* *}$ & $.314^{* *}$ & $.184^{* *}$ & $.240^{* *}$ & $.209^{* *}$ & $.190^{* *}$ & $.216^{* *}$ & $.184^{* *}$ & $.203^{* *}$ & $.357^{* *}$ \\
\hline LMX2 & $.310^{* *}$ & $.221^{* *}$ & $.138^{* *}$ & $.147^{* *}$ & $.169^{* *}$ & $.148^{* *}$ & $.163^{* *}$ & $.131^{* *}$ & $.130^{* *}$ & $.269^{* *}$ \\
\hline LMX3 & $.347^{* *}$ & $.241^{* *}$ & $.123^{*}$ & $.210^{* *}$ & $.214^{* *}$ & $.176^{* *}$ & $.218^{* *}$ & $.199^{* *}$ & $.207^{* *}$ & $.331^{* *}$ \\
\hline LMX4 & $.368^{* *}$ & $260^{* *}$ & $.107^{*}$ & $169^{* *}$ & $.186^{* *}$ & $.152^{* *}$ & $.226^{* *}$ & $.160^{* *}$ & $.181^{* *}$ & $.322^{* *}$ \\
\hline LMX5 & $.290^{* *}$ & $.197^{* *}$ & .091 & $.142^{* *}$ & $.147^{* *}$ & $.170^{* *}$ & $.161^{* *}$ & $.128^{* *}$ & $.133^{* *}$ & $.264^{* *}$ \\
\hline LMX6 & $.349^{* *}$ & $.251^{* *}$ & $.183^{* *}$ & $.202^{* *}$ & $.233^{* *}$ & $.165^{* *}$ & $.196^{* *}$ & $.177^{* *}$ & $.253^{* *}$ & $.273^{* *}$ \\
\hline LMX7 & $.321^{* *}$ & $.244^{* *}$ & $.126^{*}$ & $.206^{* *}$ & $.195^{* *}$ & $.175^{* *}$ & $.207^{* *}$ & $.129^{* *}$ & $.187^{* *}$ & $.364^{* *}$ \\
\hline
\end{tabular}

Source: Authors' own research

Table 7. The correlations between the LMX relationship and the personal and ethical development of the pupils

\begin{tabular}{lll}
\hline & SPD & SED \\
\hline LMX1 & $.298^{* *}$ & $.356^{* *}$ \\
LMX2 & $.253^{* *}$ & $.339^{* *}$ \\
LMX3 & $.295^{* *}$ & $.411^{* *}$ \\
LMX4 & $.291^{* *}$ & $.408^{* *}$ \\
LMX5 & $.247^{* *}$ & $.382^{* *}$ \\
LMX6 & $.324^{* *}$ & $.437^{* *}$ \\
LMX7 & $.319^{* *}$ & $.396^{* *}$ \\
\hline
\end{tabular}

Source: Authors' own research

Linear regression analysis was applied to test the predictive effect of the LMX relationship on the quality of the teaching process and the personal and ethical development of the pupils. The results are shown in Tables 8 and 9.

Table 8: The results of regression analysis: the predictive effect of the LMX relationship on the teaching process

\begin{tabular}{c|ccccccc|ccc}
\hline Dep. & LMX1 & LMX2 & LMX3 & $\begin{array}{c}\text { Indep. } \\
\text { LMX4 } \\
\beta\end{array}$ & LMX5 & LMX6 & LMX7 & $\mathrm{R}^{2}$ & $\mathrm{~F}$ & Sig. \\
\hline TP1 & $.232^{* *}$ & -.068 & .076 & .188 & -.051 & $.187^{*}$ & -.092 & .179 & 12.394 & .000 \\
TP2 & .281 & -0.68 & -.013 & .127 & -.064 & .139 & -0.48 & .114 & 7.311 & .000 \\
TP3 & $.200^{* *}$ & .062 & -.024 & -.088 & -.087 & $.254^{* *}$ & -.107 & .058 & 3.504 & .001 \\
TP4 & $.195^{* *}$ & -.137 & .129 & -0.17 & -.078 & .141 & .033 & .075 & 4.605 & .000 \\
TP5 & .122 & -.067 & .135 & .002 & -.104 & $.221^{* *}$ & -.040 & .072 & 4.409 & .000 \\
TP6 & .126 & -.047 & .053 & -.031 & .068 & .054 & 014 & .044 & 2.647 & .011 \\
TP7 & .117 & -.140 & .103 & .160 & -.067 & .064 & .029 & .069 & 4.230 & .001 \\
TP8 & .144 & -.101 & $.216^{*}$ & .023 & -.053 & $.165^{*}$ & -.167 & .060 & 3.659 & .001 \\
TP9 & .139 & -.130 & $.207^{*}$ & .023 & -.137 & $.304^{*}$ & -.053 & .092 & 5.768 & .000 \\
TP10 & $.194^{*}$ & -.158 & .087 & .134 & -.039 & -.025 & $.226^{* *}$ & .163 & 11.091 & .000 \\
\hline
\end{tabular}

Source: Authors' own research 
Table 9. The results of the regression analysis: the predictive effect of LMX on the personal and ethical development of the pupils

\begin{tabular}{c|ccccccc|ccc}
\hline & & & \multicolumn{3}{c}{ Indep. } & & & \\
Dep. & LMX1 & LMX2 & LMX3 & LMX4 & LMX5 & LMX6 & LMX7 & $\mathrm{R}^{2}$ & F & Sig. \\
& & & & $\beta$ & & & & & & \\
\hline SPD & $.139^{*}$ & -.100 & .064 & .065 & -.066 & $.198^{*}$ & .095 & .132 & 8.682 & .000 \\
SED & .103 & -.144 & .162 & .115 & .043 & $.252^{* *}$ & .001 & .228 & 16.800 & .000 \\
\hline
\end{tabular}

Source: Authors' own research

\section{Discussion of the results}

\subsection{Discussion of the results of the influence of leadership}

Table 2 shows the results of the correlation analysis between the dimensions of leadership and the teaching process dimensions. It can be seen that all the correlations are statistically significant and positive. On this basis, hypothesis H1a was confirmed. From the leadership dimensions, the most significant positive impact on the teaching process dimensions was achieved by L4 - intellectual stimulation, and then L1 - the leader's core transformational behaviour. Teachers respond to intellectual stimulation from the principal and this in turn encourages them to achieve better results in their work, which is clearly seen in the quality of the teaching process. Also, good school leadership is a factor that provides teachers with security and brings the school to the desired future, which gives them the stability necessary to concentrate on their work, which is teaching.

From the leadership dimensions, the weakest influence on the dimensions of the teaching process was exerted by dimension L6 - punishing behaviour (punishment), followed by dimension L3 - the stimulating behaviour of the leader. It should be borne in mind that although these dimensions have a positive impact on the teaching process, this impact is lower than that of the other leadership dimensions. Therefore, punishments can have some effects, but their use is the least powerful tool school principals can use in their endeavours to improve the quality of the teaching process. The demonstration of understanding and feeling in the correlation analysis has slightly less influence on the teaching process. However, dimension L3 - the stimulating behaviour of the leader shows a significant predictive effect on the teaching process, as can be seen in the results of the regression analysis (Table 4).

From the teaching process dimensions, dimensions TP1 - lesson planning, TP2 preparing classes and TP10 - reporting are under the strongest influence of the leadership dimensions. These are, therefore, the dimensions that relate to activities that are beyond the immediate teaching in class, so the influence of the leader is the greatest. It is the leader who can encourage the achievement of prescribed goals and tasks, communication among teachers, the harmonization of materials across different 
subjects, the use of professional literature, etc. What is interesting is that the dimensions TP1 - lesson planning and TP2 - preparing classes have the weakest average values from all the dimensions of the teaching process (descriptive statistics, Table 1). This result points to the importance of leadership in this segment, i.e. it is precisely by engaging the leaders (principals) that the weakest dimensions of the teaching process can be improved.

The leadership dimensions have the smallest influence on the dimensions TP8 learning methods, TP3 - communication and cooperation and TP6 - correlation and application of knowledge. These dimensions relate to the teachers' direct work with pupils. These dimensions may be said to be more dependent on the teachers' professional competences than on any other dimensions, making the principal's ability to influence them significantly lower.

Table 3 shows the results of the correlation analysis between the leadership dimensions and the dimensions of the pupils' personal and ethical development. It can be seen that all the correlations are statistically significant and positive. On this basis, hypothesis H1b was confirmed. From the leadership dimensions, the dimensions of the pupils' personal and ethical development are most influenced by L1 - the leader's core transformational behaviour and L4 - intellectual stimulation. These dimensions of leadership behaviour most favour the creation of an atmosphere in the school which contributes to the personal and ethical development of pupils. The smallest impact is again achieved by dimension L6 - punishing behaviour (punishment), followed by L2 high performance expectation. It is obvious that these are the dimensions which can exert a certain degree of pressure on teachers, which is in turn transferred to the overall atmosphere in the school's collective, and then to the reduced effects on the pupils' development. Leadership influences the dimensions of SED - pupils' ethical development, rather than the SPD dimensions - pupils' personal development.

Based on these results from Table 4, it can be noted that the leadership dimensions have a predictive effect on the dimensions of the teaching process, i.e. hypothesis H1c is confirmed. The highest $\mathrm{R}^{2}$ values occur for the dimensions TP1 lesson planning, TP2 - preparing classes and TP10 - reporting, while the lowest are recorded for dimensions TP3 - communication and cooperation, TP8 - learning methods and TP6 - correlation and application of knowledge. These results are completely consistent with the results of the correlation analysis. The strongest effect is achieved by dimension L3 - the incentive behaviour of the leader, which is contrary to the results of the correlation analysis. It is obvious that in the overall effect of leadership behaviour, the support and understanding of the leader appears as a significant predictor of the dimensions of the teaching process. It follows from this that the effect of dimension L3 - the incentive behaviour of the leader must not be neglected in efforts to improve the teaching process. It should also be noted that dimension L6 punishing behaviour (punishment) does not have a predictive effect at all, even it is 
slightly negative. This result is consistent with the results of the correlation analysis. The same can be said for the predictive effects of the other leadership dimensions. According to Table 5, it can be concluded that there is a predictive effect of the leadership dimensions on the dimensions of the pupils' personal and ethical development, thus confirming hypothesis H1d. It is easily noticed that the SED dimensions - pupils' ethical development have a higher $\mathrm{R}^{2}$ determination index than the SPD dimensions - pupils' personal development, which is a result consistent with the results of the correlation analysis.

Overall, the results related to the influence of leadership are consistent with those gained in a large number of existing studies, for example (Donaldson Jr., 2007; Odhiambo \& Hii, 2012; Aubrey et al., 2013; Vilkinas \& Ladyshewsky, 2012).

\subsection{Discussion of the results of the impact of the LMX relationship}

The results of the correlation analysis between the LMX relationship and the dimensions of the teaching process are given in Table 6 . It can be seen that almost all the correlations are statistically significant and positive. Therefore, it can be concluded that hypothesis H2a is confirmed. From the LMX relationship items, items LMX1 - the degree of information that the principal is satisfied with your work, and then LMX6 the degree of confidence in the principal's decisions have the most powerful positive influence on the dimensions of the teaching process. Teachers want to obtain feedback on their work, and it is important for them to gain recognition for their work and effort, to receive appropriate praise and to enhance their reputation in the collective. Also, the teaching process is influenced by the level of trust in the principal's decisions, i.e. the good strategic and operational management of the school. Here, there is a noticeable similarity and analogy with the results of the influence of leadership on the teaching process: from the leadership dimensions, the most powerful positive influence on the dimensions of the teaching process is achieved by dimensions L4 - intellectual stimulation, and then L1 - the leader's core transformational behaviour.

From the LMX relationship, item LMX5 - the degree to which the principal is ready to "back you up", even at his own risk, followed by LMX2 - the degree to which the principal understands your work problems and needs, have the lowest impact on the dimensions of the teaching process. Although these items have a positive impact on the teaching process, this effect is somewhat weaker than in other aspects of the LMX relationship. The teachers do not expect a great deal of support or understanding from their principals, and their primarily concern is a certificate for their work and security regarding school management. Based on this, it can be said that the teachers have shown a high degree of maturity and confidence in their work and their own abilities. In this part, there is also a significant similarity with the results of the influence of 
leadership on the teaching process. From the leadership dimensions, in addition to dimension L6 - punishing behaviour (punishment), as a very unpopular form of leadership, dimension L3- the incentive behaviour of the leader also has a very weak influence on the dimensions of the teaching process.

From the dimensions of the teaching process, dimensions TP1 - lesson planning, TP10 - reporting and TP2 - preparing classes are under the strongest impact of the LMX relationship. A quality LMX relationship creates the conditions where it is both natural and normal to have good relationships and communication not only with the principal, but also with colleagues and teaching staff, as well as with pupils and their parents. It is especially important that the dimensions TP1 - lesson planning and TP2 preparing classes have the lowest average values of all the teaching process dimensions (descriptive statistics, Table 1), proving that raising the quality of the LMX relationship can be used as an effective tool to improve lesson planning and preparing classes. The results of the study of the influence of leadership on the teaching process have proved practically the same result, and it can be concluded that the improvement of the teaching process can be effectively achieved by a broader approach to the overall improvement of leadership behaviour and the LMX relationship.

Like the influence of the leadership dimensions, the LMX relationship items also have the smallest influence on the dimensions of the teaching process TP3 communication and cooperation, TP8 - learning methods and TP6 - correlation and application of knowledge. The explanation is similar to the previous discussion: these dimensions, perhaps to the greatest extent, include the immediate work of teachers with pupils. Thus, these dimensions largely depend on the teachers themselves, their engagement, their competence and their abilities: the teachers cannot be assisted by the principal in classes and a good relationship with the principal cannot help them.

The results of the correlation analysis between the LMX relationship and the dimensions of the students' personal and ethical development are given in Table 7. All the correlations are statistically significant and positive, and it can be concluded that all the aspects of the LMX relationship affect the personal and ethical development of students. This confirms hypothesis H2b. From the LMX relationship items, LMX6 the degree of confidence in managerial decisions and LMX7 - efficiency of working relationships with the principal are the most influential on the dimensions of the pupils' personal and ethical development. The existence of confidence in the principal's work and decisions, as well as the efficiency of relations between the principal and teachers, creates stable conditions for the development and progress of the school, as well as a stable internal environment and a system of interpersonal relations. All this contributes to the creation of a school climate which favours the personal and ethical development of pupils. The LMX relationship items which have the smallest influence on the dimensions of pupils' personal and ethical development are LMX2 - the degree to which the principal understands your work problems and needs, followed by LMX5 - 
the degree to which the principal is ready to "back you up", even at his own risk. These items are strictly directed at the relationship between principals and teachers, and such details are often not known to pupils. Similar to the case of the influence of the leadership dimensions, the LMX relationships items also have a greater impact on the dimensions of SED - pupils' ethical development rather than on the SPD dimensions pupils' personal development.

According to Table 8, it can be concluded that the LMX relationship items have a predictive effect on the teaching process dimensions, thus confirming hypothesis $\mathrm{H} 2 \mathrm{c}$. The highest $\mathrm{R}^{2}$ values occur for dimensions TP1 - lesson planning, TP10 reporting and TP2 - preparing classes, and the lowest for dimensions TP6 - correlation and application of knowledge, TP3 - communication and cooperation and TP8 learning methods. These results are almost completely consistent with the results of the correlation analysis. It should also be noted that these results are very close to the results of the regression analysis in which the leadership dimensions are the independent variables, and the dimensions of the teaching process the dependent variables (Table 4). Obviously, the teaching process dimensions are similarly dependent on leadership and the LMX relationships.

The results from Table 9 show that there is a predictive effect of the LMX relationship on the dimensions of pupils' personal and ethical development, so $\mathrm{H} 2 \mathrm{~d}$ hypothesis is confirmed. It should be noted that the SED dimensions - pupils' ethical development have a higher $\mathrm{R}^{2}$ determination index compared to the SPD dimensions pupils' personal development, and that this value is at its highest when the values of this index are observed through the dimensions of the teaching process (Table 8). The conclusion in this part is that the SED dimensions - pupils' ethical development are under the most predictive effect and the strongest impact of the LMX relationship items. This result is consistent with the results of the correlation analysis. The results related to the impact of the LMX relationships are consistent with those gained in some previous research studies (Brimecombe et al., 2014; Erdogan et al., 2004; Somech, 2003).

\section{Conclusion}

The study confirmed all eight specific hypotheses. Hence, the basic hypothesis of the research was confirmed: leadership and the LMX relationship have a statistically significant influence on the quality of the teaching process and the personal and ethical development of pupils in elementary schools in Serbia.

All the leadership dimensions are statistically significant and positively influence the teaching process positively. From the leadership dimensions, the most significant positive impact on the dimensions of the teaching process is achieved by dimensions L4 - intellectual stimulation, and then L1 - the leader's core 
transformational behaviour. It should also be emphasized that dimension L3 - the leader's incentive behaviour shows a significant predictive effect on the teaching process. All the LMX relationship items are statistically significantly and positively influence the teaching process. The strongest positive impact on the teaching process dimensions is exerted by items LMX1 - the degree of information that the principal is satisfied with your work, followed by LMX6 - the degree of confidence in the principal's decision making. Three dimensions of the teaching process are under the greatest influence of leadership and LMX relationship: TP1 - lesson planning, TP2 preparing classes and TP10 - reporting. Given that the dimensions TP1 - lesson planning and TP2 - preparing classes have the least average grades from all dimensions of the teaching process (descriptive statistics, Table 1), it is clear that leadership and LMX relationship can significantly contribute to raising the level of quality of these, important dimensions of the teaching process.

Generally, the strongest influence of leadership and the LMX relation on the teaching process dimensions occurs with dimensions that include activities outside the classroom, while the weakest impact exists for those dimensions which are directly related to teaching activities in class. It should be emphasized that both the leadership dimensions and the features of the LMX relationship have a greater impact on the SED dimensions - pupils' ethical development, rather than the SPD dimensions - pupils' personal development. Primary school principals should develop an awareness of their important and key roles in improving the various aspects of organizational behaviour in schools, and then enhancing the quality of the teaching process, and the personal and ethical development of pupils. The research has clearly shown (a few results suggest) that teachers do not receive sufficient feedback on their work. The proposal for principals is to pay more attention to these issues. In general, principals should continuously work on improving leadership and LMX relationships. The application of such defined proposals would contribute to the improvement of the quality of the teaching process as well as the personal and ethical development of pupils. It should be emphasized that these proposals do not require any special financial investments, or too much engagement on the part of principals.

\section{References}

Aubrey, C., Godfrey, R. \& Harris, A. (2013). How Do They Manage? An Investigation of Early Childhood Leadership. Educational Management Administration \& Leadership, 41(1), 5-29. Doi: https://doi.org/10.1177/1741143212462702

Bogler, R., Caspi, A. \& Roccas, S. (2013). Transformational and Passive Leadership: An Initial Investigation of University Instructors as Leaders in a Virtual Learning Environment. Educational Management Administration \& Leadership, 41(3), 372-392. Doi: https://doi.org/10.1177/1741143212474805 
Bojanić, M., Bukinac, B., Vasić, J., Vraneš, N., Đorđević, R., Đurđević, R., et al. (2005). Handbook for self-evaluation and evaluation of school work. Ministry of Education and Sports of the Republic of Serbia, British Council Serbia and Montenegro.

Brimecombe, M., Magnusen, M.J. \& Bunds, K. (2014). Navigating the storm: A counterproductive work behavior and leadership case study in a Division I FBS School. Sport Management Review, 17(2), 219-237. Doi:

https://doi.org/10.1016/j.smr.2013.03.001

Bryman, A. (1992). Charisma and leadership in organizations. London: Sage.

Burns, J.M. (1978). Leadership. New York: Harper \& Row.

Cannella, A.A.Jr. \& Monroe, M.J. (1997). Contrasting perspectives on strategic leaders: Toward a more realistic view of top managers. Journal of Management, 23(3), 213-237. Doi: https://doi.org/10.1177/014920639702300302

Dansereau, F., Graen, G.B. \& Haga, W. (1975). A vertical dyad linkage approach to leadership in formal organizations. Organizational Behavior and Human Performance, 13, 46-78. Doi: https://doi.org/10.1016/0030-5073(75)90005-7

Dienesch, R.M. \& Liden, R.C. (1986). Leader-member exchange model of leadership: A critique and further development. Academy of Management Review, 11(3), 618-634. Doi: https://doi.org/10.5465/amr.1986.4306242

Donaldson, Jr., G.A. (2007). What Do Teachers Bring to Leadership? Educational leadership, 65(1), 26-29.

Dragojlović, V., Mihailović, B. \& Novaković, S. (2018). Marketing activities for the purpose of marketing culture development in education and educational institutions. Ekonomika, 64(4), 135-146.

Đorđević, B., Ivanović-Đukić, M., Lepojević, V. \& Milanović, S. (2019). The influence of organizational justice on corporate performances. Strategic Management, 24(3), 014-023. Doi: https://doi.org/10.5937/StraMan1903014D

Erdogan, B., \& Enders, J. (2007). Support from the top: supervisors' perceived organizational support as a moderator of leader-member exchange to satisfaction and performance relationships. Journal of Applied Psychology, 92(2), 321-330. Doi: https://doi.org/10.1037/0021-9010.92.2.321

Erdogan, B., Kraimer, M.L. \& Liden, R.C. (2004). Work value congruence and intrinsic career success: the compensatory roles of leader-member exchange and perceived organizational support. Personnel Psychology, 57(2), 305-332. Doi: https://doi.org/10.1111/j.1744-6570.2004.tb02493.x 
Erić Nielsen, J., Stojanović-Aleksić, V. \& Zlatanović, D. (2019). The challenges of managing the entrepreneurial organization. Ekonomika, 65(2), 87-98. Doi: https://doi.org/10.5937/ekonomika1902087E

Ferris, G.R., Judge, T.A., Chachere, J.G. \& Liden, R.C. (1991). The age context of performance evaluation decisions. Psychology and Aging, 6(4), 616-622.

Graen, G.B. \& Uhl-Bien, M. (1995). Relationship-based approach to leadership: Development of leader member exchange (LMX) theory of leadership over 25 years, applying a multilevel multidomain perspective. The Leadership Quarterly, 6(2), 219247. Doi: https://doi.org/10.1016/1048-9843(95)90036-5

Hallinger, Ph. \& Heck, R.H. (2010). Leadership for Learning: Does Collaborative Leadership Make a Difference in School Improvement? Educational Management Administration \& Leadership, 38(6), 654-678. Doi:

https://doi.org/10.1177/1741143210379060

Howell, J.M., Neufeld, D.J. \& Avolio, B.J. (2005). Examining the relationship of leadership and physical distance with business unit performance. The Leadership Quarterly, 16(2), 273-285. Doi: https://doi.org/10.1016/j.leaqua.2005.01.004

Khasawneh, S., Omari, A. \& Abu-Tineh, A. (2012). The Relationship between Transformational Leadership and Organizational Commitment: The Case for Vocational Teachers in Jordan. Educational Management Administration \& Leadership, 40(4), 494-508. Doi: https://doi.org/10.1177/1741143212438217

Ling, Y., Simsek, Z., Lubatkin, M.H. \& Veiga, J.F. (2008). Transformational leadership's role in promoting corporate entrepreneurship: examining the CEO-TMT interface. Academy of Management Journal, 51(3), 557-576. Doi:

https://doi.org/10.5465/amj.2008.32626023

MacKenzie, S.B., Podsakoff, Ph.M. \& Rich, G.A. (2001). Transformational and transactional leadership and salesperson performance. Journal of the Academy of Marketing Science, 29(2), 115-134. Doi: https://doi.org/10.1177/03079459994506

Odhiambo, G. \& Hii, A. (2012). Key Stakeholders' Perceptions of Effective School Leadership. Educational Management Administration \& Leadership, 40(2), 232-247. Doi: https://doi.org/10.1177/1741143211432412

Pashiardis, P., Savvides, V., Lytra, E. \& Angelidou, K. (2011) Successful School Leadership in Rural Contexts: The Case of Cyprus. Educational Management Administration \& Leadership, 39(5), 536-553. Doi: https://doi.org/10.1177/1741143211408449

Pellegrini, E.K. \& Scandura, T.A. (2006). Leader-member exchange (LMX), paternalism, and delegation in the Turkish business culture: An empirical investigation. 
Journal of International Business Studies, 37(2), 264-279. Doi:

https://doi.org/10.1057/palgrave.jibs.8400185

Podsakoff, Ph.M., Todor, W.D., Grover, R.A. \& Huber, V.L. (1984). Situational moderators of leader reward and punishment behaviors: fact or fiction? Organizational Behavior and Human Performance, 34(1), 21-63. Doi: https://doi.org/10.1016/00305073(84)90036-9

Podsakoff, Ph.M., MacKenzie, S.B., Moorman, R.H. \& Fetter, R. (1990).

Transformational leader behaviors and their effects on followers' trust in leader, satisfaction, and organizational citizenship behaviors. The Leadership Quarterly, 1(2), 107-142.

Ross, J., Valenzuela, M., Intindola, M. \& Flinchbaugh, C. (2017). Preparing potential leaders: Facilitating a learning experience on LMX and fairness in the workplace. The International Journal of Management Education, 15(1), 84-97. Doi: https://doi.org/10.1016/j.ijme.2017.01.006

Seabright, M.A., Leventhal, D.A. \& Fichman, M. (1992). Role of individual attachments to the dissolution of inter-organisational relationships. Academy of Management Journal, 35, 22-60. Doi: https://doi.org/10.5465/256475

Sokolov Milovančević, N., Gračanac, A. \& Kitić, A. (2019). Leadership in Serbian healthcare system. Ekonomika, 65(1), 57-65. Doi:

https://doi.org/10.5937/ekonomika1901057M

Somech, A. (2003). Relationships of participative leadership with relational demography variables: a multi-level perspective. Journal of Organizational Behavior, 24(8), 1003-1018. Doi: https://doi.org/10.1002/job.225

Stojanović, S. \& Marić, S. (2018). Communication as a measure of leadership performance. Anali Ekonomskog fakulteta u Subotici, 40, 81-94. Doi:

https://doi.org/10.5937/AnEkSub1840081S

Strukan, E., Terek, E. and Nikolić, M. (2019). Impact of leadership on interpersonal trust at work in enterprises in Bosnia and Herzegovina. Journal of Engineering Management and Competitiveness (JEMC), 9(1), 48-59. Doi:

https://doi.org/10.5937/JEMC1901048S

Vilkinas, T. \& Ladyshewsky, R.K. (2012). Leadership Behaviour and Effectiveness of Academic Program Directors in Australian Universities. Educational Management Administration \& Leadership, 40(1), 109-126. Doi:

https://doi.org/10.1177/1741143211420613 